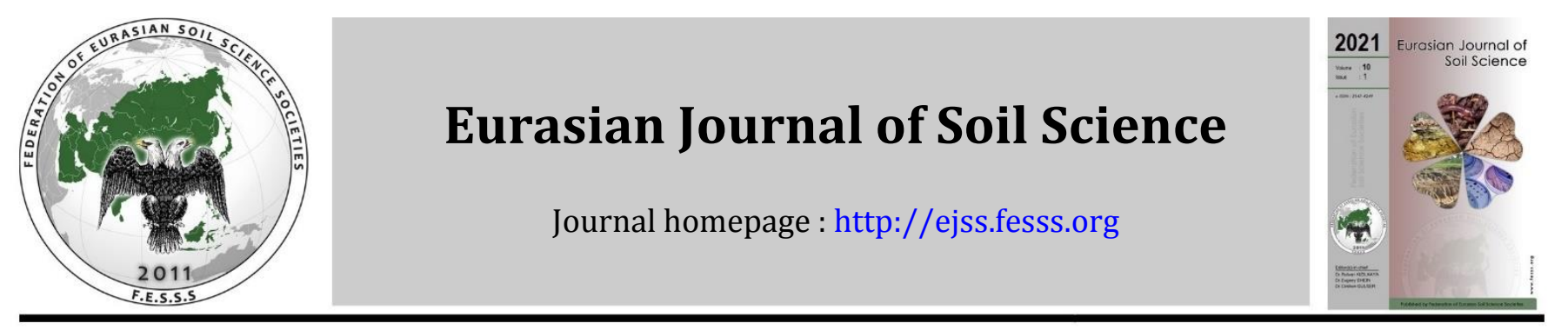

\title{
Assessment of ecotoxicity of the bismuth by biological indicators of soil condition
}

\section{Lyudmila Sudina *, Sergey Kolesnikov, Tatiana Minnikova, Kamil Kazeev, Svetlana Sushkova, Tatiana Minkina}

Southern Federal University, Academy of Biology and Biotechnology, Rostov-on-Don, Russia

\section{Article Info}

Received : 11.11 .2020

Accepted : 12.04 .2021

Available online : 23.04.2021

\section{Author(s)}

L. Sudina *

S. Kolesnikov

T. Minnikova

K. Kazeev

S. Sushkova

T. Minkina

* Corresponding author

\section{Abstract}

The present study was performed for the ecotoxicity assessment of the bismuth (Bi) effect on the biological indicators of soil condition: total number of soil bacteria, catalase activity, dehydrogenases activity and germination of Radish seeds and length of the Radish roots. Three soil types with significantly different resistance ability to heavy metal pollution were studied: Haplic Chernozems Calcic, Haplic Arenosols Eutric and Haplic Cambisols Eutric.Soil contamination of Bi was simulated in the lab (3, 30 and $300 \mathrm{mg} \mathrm{kg}^{-1}$ dry weight). Changes in the biological parameters of the soil were assessed at 10 day treatment. The data obtained showed that the soils contaminated with Bi in South Russia generally characterized by oppression of the biological properties. The total number of bacteria and enzymatic activity (catalase and dehydrogenases) decreased over the $\mathrm{Bi}$ contamination. The indicators of phytotoxicity (germination of radish seeds) increase when bismuth 3 and 30 $\mathrm{mg} \mathrm{kg}^{-1}$ is added to the soil. The degree of deterioration in biological properties depends on the concentration of $\mathrm{Bi}$ in the soil and the period of time after the onset of pollution. Resistance of soil types to Bi pollution can be described by the following decreasing series: Haplic Chernozem Calcic > Haplic Arenosols Eutric $>$ Haplic Cambisols Eutric. The following regional maximum permissible concentrations (rMPC) of Bi have been proposed: Haplic Chernozem Calcic - 8.5 mg kg-1 , Haplic Arenosols Eutric - $2.2 \mathrm{mg} \mathrm{kg}^{-1}$ and Haplic Cambisols Eutric - 1.8 $\mathrm{mg} \mathrm{kg}^{-1}$.

Keywords: Biotesting, bismuth, pollution, soil biological properties.

(C) 2021 Federation of Eurasian Soil Science Societies. All rights reserved

\section{Introduction}

Soil pollution with heavy metals is a serious problem in all countries of the world (Zhang et al., 2011a; Murtić et al., 2020). Bismuth (Bi) is characterized by a low content in the Earth's crust (Kabata Pendias and Pendias, 2010). Bi is used along with nitrogen, carbon and chlorine (Kasimov and Vlasov, 2012). The use of Bi leads to an increased content of Bi in all environmental components (Meyer et al., 2007; Soriano et al., 2012). The main sources of pollution of the environment and soil with Bi are the metalworking industry (Cortada et al., 2012) and cars (Xiong et al., 2015). Ore deposits containing Bi increase its background content in the soil cover up to 300 times (Yurgenson and Gorban, 2017). The increased content of Bi in soil leads to its accumulation in plants (Wei et al., 2011) and in the human body, causing many pathological conditions (Li et al., 2014).

A number of ongoing studies reveal more and more evidence of the negative effects of Bi on soil enzymatic activity and soil bacteria (Murata, 2006), plants (Zhang et al., 2011b), earthworms (Omouri et al., 2018), and humans (Liu et al., 2011). However, several studies have found a stimulating effect of Bi nanoparticles on 
plant length (Nagata, 2015). The effect of Bi on the biological properties of soils remains insufficiently studied.

The main objective of this study was to estimate of ecotoxicity of the bismuth by biological indicators of soil condition: total number of soil bacteria, catalase activity, dehydrogenases activity and germination of Radish seeds and length of the Radish roots.

\section{Material and Methods}

\section{Soil sampling}

A variety of soils found in the South of Russia with considerably different properties as to their resistance to heavy metal contamination were selected as study objects: Haplic Chernozem Calcic, Haplic Arenosols Eutric and Haplic Cambisols Eutric (WRB, 2015). Soil samples were taken from the upper soil layer $(0-0.10 \mathrm{~m})$ because of the most intensive heavy metals accumulation in the upper soil layer from the territory of the southern Russia located far from potential contamination sources by Bi (Figure 1) (Kabata Pendias and Pendias, 2010). The map of sample The data provides on the particular places of soil sampling and a brief analysis of their basic physical and chemical soil indicators (Table 1).

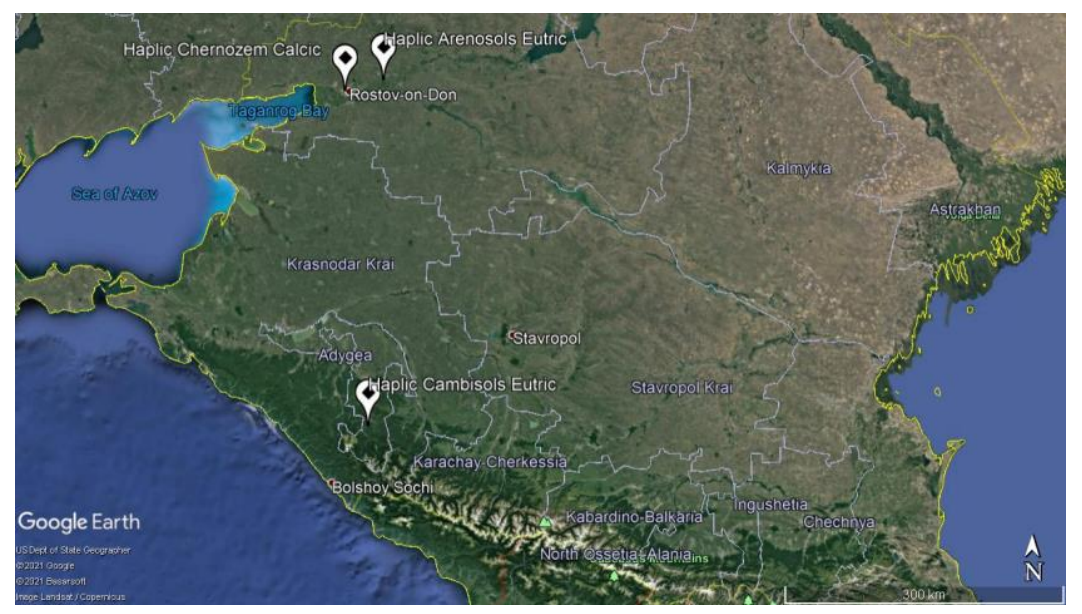

Figure 1. Soil sampling map

Table 1. Description of soil sampling areas

\begin{tabular}{|c|c|c|c|c|c|c|}
\hline Soil type & Sampling area & $\begin{array}{l}\text { Geographical } \\
\text { coordinates }\end{array}$ & Land type & $\begin{array}{c}\text { Humus } \\
\text { content, \% }\end{array}$ & $\mathrm{pH}$ & $\begin{array}{l}\text { Particle size } \\
\text { distribution }\end{array}$ \\
\hline $\begin{array}{l}\text { Haplic Chernozem } \\
\text { Calcic }\end{array}$ & $\begin{array}{l}\text { The Botanical Garden, } \\
\text { Southern Federal } \\
\text { University, } \\
\text { Rostov-on-Don }\end{array}$ & $\begin{array}{l}47^{\circ} 14^{\prime} 17.54^{\prime \prime N} \\
39^{\circ} 38^{\prime} 33.22^{\prime \prime} \mathrm{E}\end{array}$ & Arable land & $3.70 \pm 0.10$ & $7.80 \pm 0.30$ & Heavy loam \\
\hline $\begin{array}{l}\text { Haplic Arenosols } \\
\text { Eutric }\end{array}$ & $\begin{array}{l}\text { Rostov Region, } \\
\text { Ust'-Donetskiy district }\end{array}$ & $\begin{array}{l}47^{\circ} 21^{\prime} 02.36 " \mathrm{~N} \\
40^{\circ} 09^{\prime} 34.40^{\prime \prime} \mathrm{E}\end{array}$ & $\begin{array}{l}\text { Grass and cereal } \\
\text { steppe }\end{array}$ & $2.30 \pm 0.08$ & $6.80 \pm 0.20$ & $\begin{array}{c}\text { Sandy } \\
\text { loam }\end{array}$ \\
\hline $\begin{array}{l}\text { Haplic Cambisols } \\
\text { Eutric }\end{array}$ & $\begin{array}{l}\text { Republic of Adygea, } \\
\text { Nickel settlement }\end{array}$ & $\begin{array}{l}44^{\circ} 10^{\prime} 38.94^{\prime \prime} \mathrm{N} \\
40^{\circ} 09^{\prime} 28.14^{\prime \prime} \mathrm{E}\end{array}$ & $\begin{array}{l}\text { Horn beam and } \\
\text { beech forest }\end{array}$ & $1.80 \pm 0.06$ & $5.80 \pm 0.03$ & Heavy loam \\
\hline
\end{tabular}

\section{Modelling experiments}

A model experiment on soil contamination with bismuth was carried out in triplicate. Bi values are expressed in conditionally permissible concentrations (CPCs). This is due to the detection of toxicity of heavy metals and metalloids at three background concentrations of elements in the soil (Kolesnikov et al., 2020). The average background content of $\mathrm{Bi}$ in the soil is $1 \mathrm{mg} \mathrm{kg}^{-1}$ (Alekseenko and Alekseenko, 2013). The effect of various concentrations of $\mathrm{Bi} 1,10$ and $100 \mathrm{CPC}\left(3,30\right.$ and $300 \mathrm{mg} \mathrm{kg}^{-1}$, respectively) was studied. Our interest in studying extremely high concentrations of $\mathrm{Bi}$ in soil is determined by its significant values in the area of highways up to 930-1891 $\mathrm{mg} \mathrm{kg}^{-1}$ (Elekes and Busuioc, 2010).

Bi was added to the soil in the form of nitrate. The amount of nitrate ion entering the soil at the maximum dose of $\mathrm{Bi}$ in the experiment was $0.06 \%$ of the content in $\mathrm{Bi}\left(\mathrm{NO}_{3}\right)_{3}$. In addition, unlike other $\mathrm{Bi}^{3+}$ compounds, the nitrate ion is rapidly absorbed by the soil biota (Egorysheva et al., 2015). Bi nitrate, dissolved in water, was introduced into the soil $(1 \mathrm{~kg})$ and incubated at optimal moisture content $(60 \%$ of the field moisture capacity) and a temperature of $20-22^{\circ} \mathrm{C}$ in growth chamber Binder KBW 240 (GOST RISO 22030-2009, 2009). 


\section{Analysis of biological properties}

Our attention was focused on the study of the biological properties of the soil, since they are the most sensitive to chemical attack (Kolesnikov et al., 2019). The determination of the biological properties of soils was carried out 10 days after contamination. A longer incubation period increases the difference in the state of the soil incubated in the laboratory from its state in natural conditions (Kolesnikov et al., 2020; Kizllkaya et al., 2021). Biological indicators were studied by methods of soil science and ecology (Table 2).

Table 2. Characteristics of biological indicators of soil condition

\begin{tabular}{lll}
\hline Biological indicators & Measure unit & Methods \\
\hline Total number of bacteria & $10^{9} \mathrm{in} 1 \mathrm{~g}$ of soil & luminescent microscopy \\
\hline Catalase activity & $\mathrm{ml} \mathrm{O}_{2} \mathrm{~g}^{-1}$ soil $1 \mathrm{~min}^{-1}$ & by the rate of decomposition of $\mathrm{H}_{2} \mathrm{O}_{2}$ \\
\hline $\begin{array}{l}\text { Dehydrogenases activity } \\
\text { seeds }\end{array}$ & $\mathrm{mg}$ of TPF $10 \mathrm{~g}^{-1}{\mathrm{soil} 24 \mathrm{~h}^{-1}}^{\text {according to the rate of conversion of TTC to TPF }}$ \\
\hline $\begin{array}{l}\text { The length of the radish roots } \\
\text { \% of control }\end{array}$ & $\begin{array}{l}\text { \% change germinationof radish (Raphanus sativus L.) } \\
\text { after 7 days of the experiment }\end{array}$ \\
\hline
\end{tabular}

According to the above biological indicators, the integral indicator of the biological state (IIBS) of the soil was determined (Kolesnikov et al., 2019). For the calculation of IIBS, the value of each of the above indicators on the control (in unpolluted soil) was taken as $100 \%$ and relative to it, the percentages in other experimental variants (in polluted soil) were expressed as a percentage. For the IIBS condition maximum value of each index $(100 \%)$ is chosen from array data and was expressed for other variants of experiments by Equation 1:

$$
B_{1}=\frac{B_{\mathrm{x}}}{B_{\max }} \times 100 \%
$$

where $B_{1}-$ is the relative score of the indicator; $B_{x}-$ the actual value of the indicator; $B_{\max }-$ is the maximum value of the indicator.

Then relative values of several mostly informative indices of soil biological condition such as activity of catalase and dehydrogenases, total number of bacteria, length of roots, germination of radish seeds were summed. Thereafter, average assessment point of studied indices was calculated for each variant by Equation 2:

$$
B=\frac{B_{1}+B_{2}+\ldots+B_{n}}{N}
$$

where $B-$ average estimated score of indicators; $B_{1} \ldots B_{n}-$ the relative score of the indicator; $N-$ is the number of indicators.

The integral index of the soil biological condition is calculated by Equation 3:

$$
I I B S=\frac{B}{B_{\max }} \times 100 \%
$$

where $B-$ is the average estimated score of all indicators; $B_{\max }-$ is the maximum estimated score of all indicators.

During diagnostics of contamination value of each index in non-contaminated soil is taken as $100 \%$ and with reference to it value of the same index in the contaminated soil is expressed in percent. Then determined the average value of five selected indicators for each experiment. The obtained value IIBS is expressed as a percentage concerning the control (to $100 \%$ ). The methodology used allows you to integrate the relative values of different indicators, the absolute values of which cannot be integrated since they have different units of measurement.

\section{Statistical Analyses}

To check the reliability of the results, an analysis of variance was carried out followed by the determination of the least significant difference (LSD). Data are means of three replicate biological samples. Error bars show least significant difference (LSD) at $p \leq 0.05$ level. Variation statistics (mean values, dispersion) was determined, reliability of different samples was established by using dispersion analysis (Student's $t$ test) and the correlation analysis (Pearson correlation coefficient) was conducted. Statistical data processing was carried out using Statistica 12.0 and Python 3.6.5 Matpolib package. 


\section{Results and Discussion}

\section{Variation of biological indicators in soils after bismuth contamination}

It has been established that contamination with Bi generally leads to deterioration in the biological properties of soils in the South of Russia (Figure 2, Figure 3).
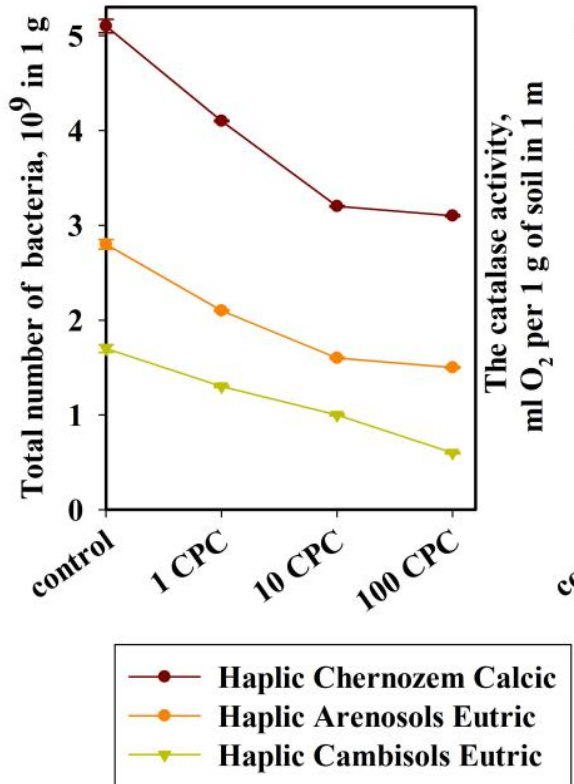
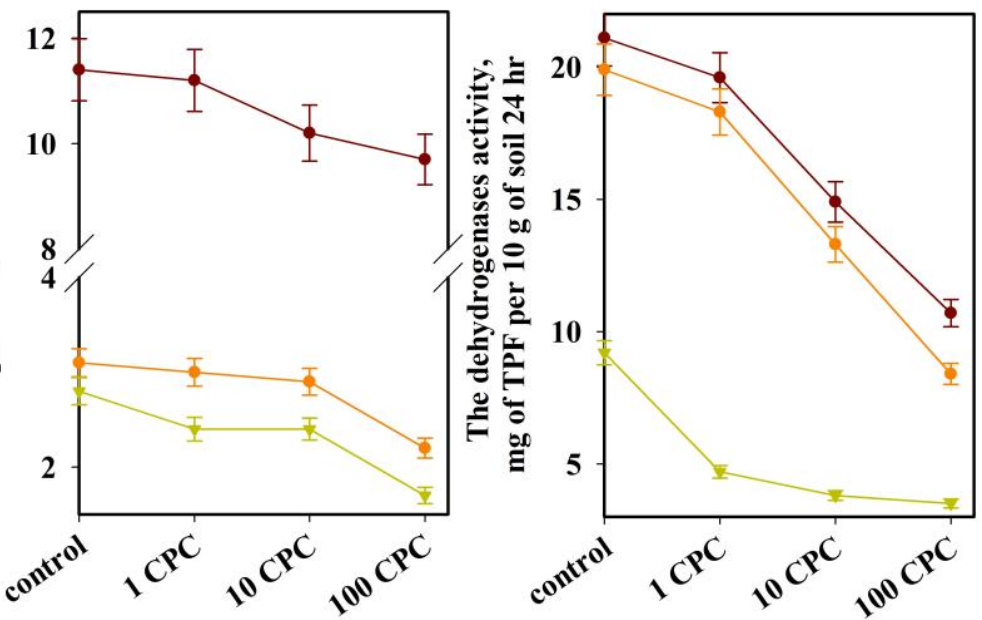

Variant of experience

Figure 2. Soil biological properties in the Bi contaminated soil

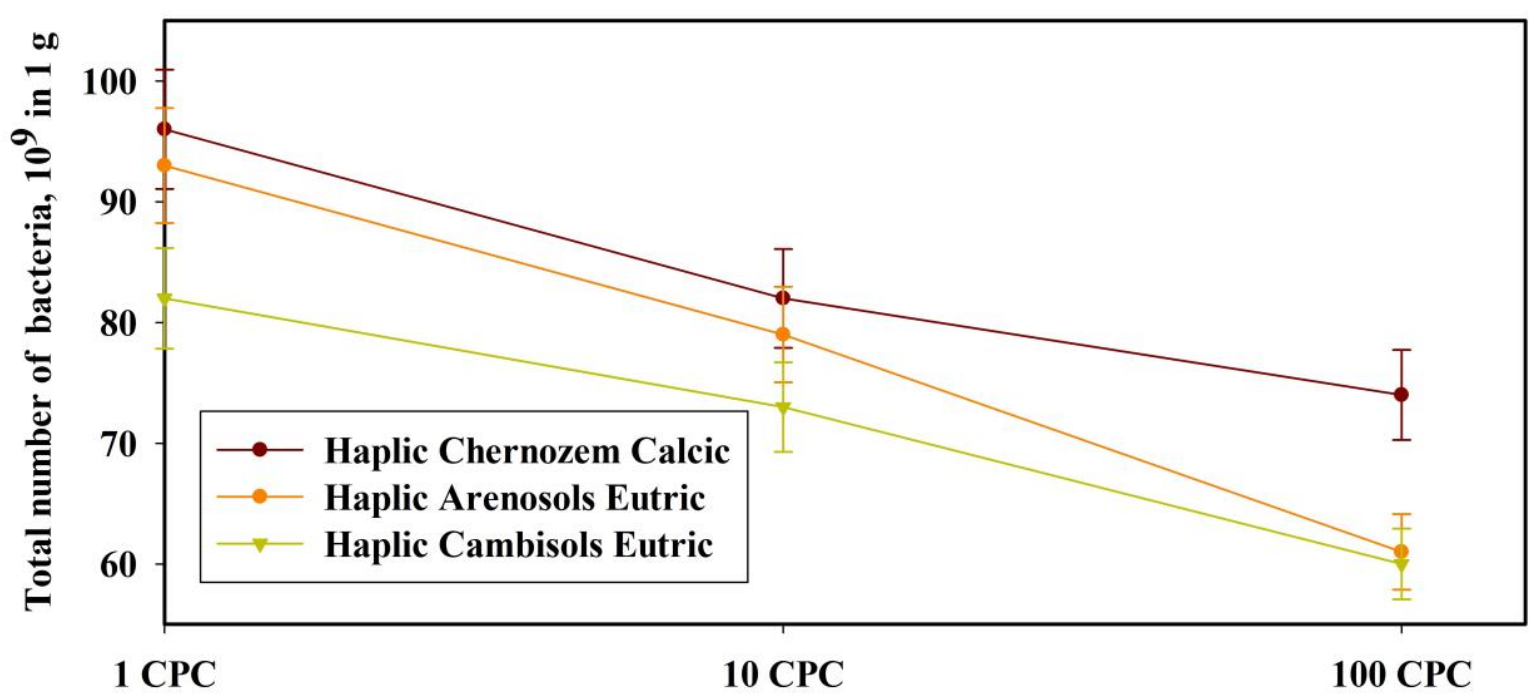

Figure 3. Total number of bacteria in the Bi contaminated soil

For Haplic Chernozem Calcic, when using Bi 10 and 100 CPC, there was a decrease in catalase activity by $11 \%$ and $15 \%$ of control, significant dehydrogenases activity- by $29 \%$ and $49 \%$ of control, radish root length- by $15 \%$ and $21 \%$ of control (Figure 4 ). The total number of bacteria decreased with the introduction of all investigated concentrations by $20 \%, 37 \%$ and 39\%, respectively, of the control (Figure 3). IIBS Haplic Chernozem Calcic with the introduction of Bi 10 and 100 CPC decreased by $18 \%$ and $26 \%$, respectively. For Haplic Cambisols Eutric, the toxic effect was already observed with $1 \mathrm{CPC}$ Bi nitrate. The maximum toxic effect was observed for the total number of bacteria - $65 \%$ of the control, catalase activity - 39\% of the control and dehydrogenases - $62 \%$ of the control. IIBS Haplic Cambisols Eutric decreased with the introduction of 1, 10 and 100 CPC Bi by 18, 27 and 40\%, respectively. Murata (2006) established the degree of suppression of the total number of bacteria and activity of dehydrogenases when Bi compounds were introduced into Haplic Cambisols Eutric. 

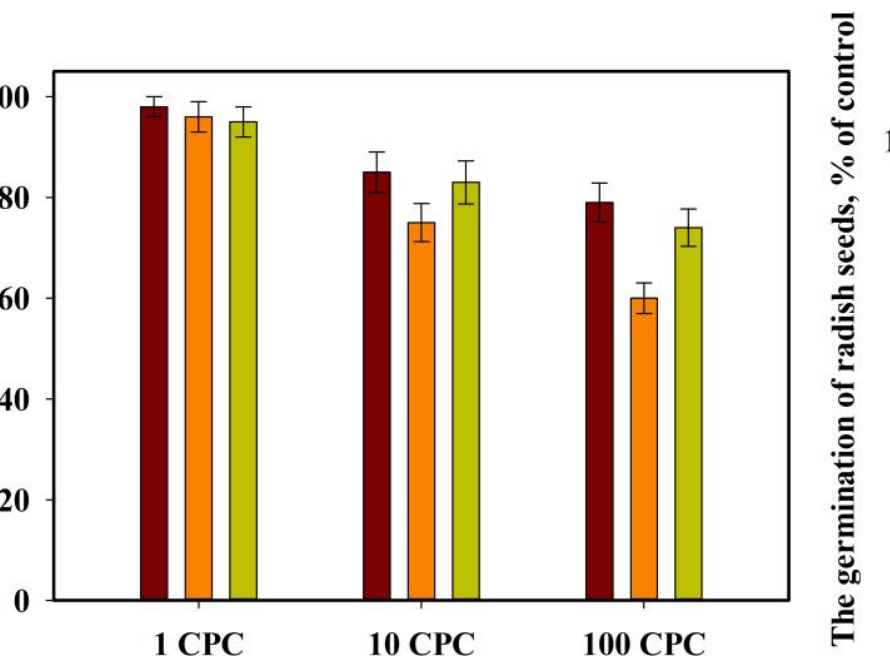

Variant of experience
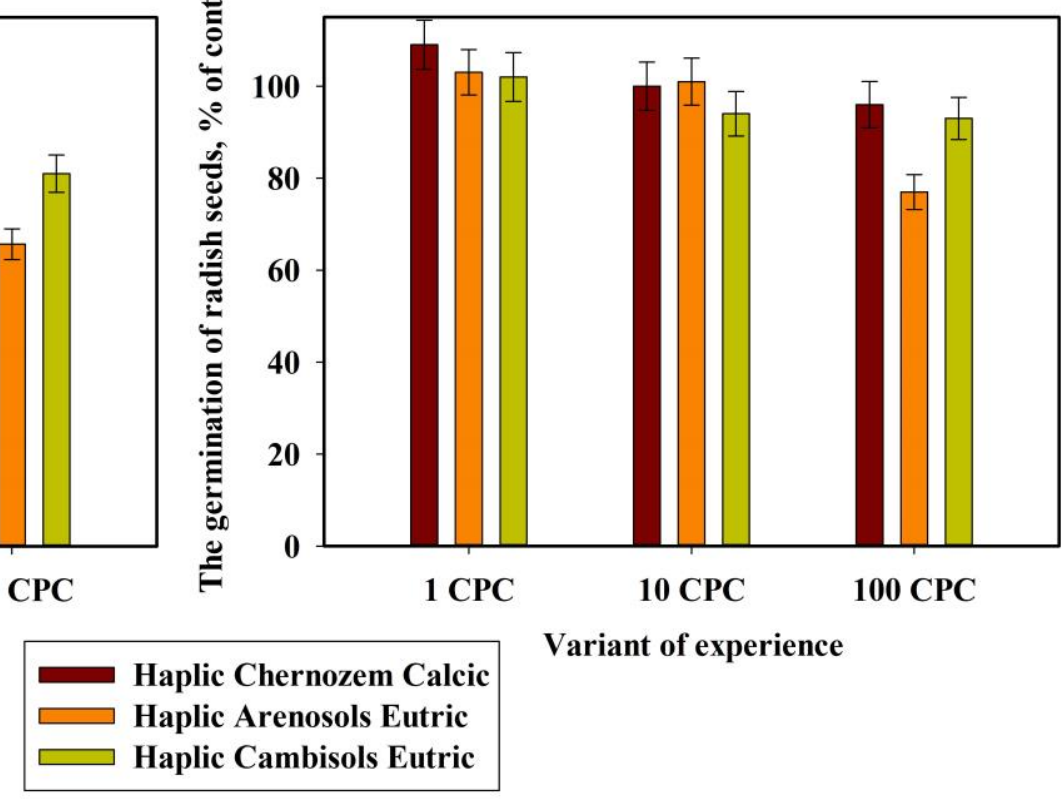

Variant of experience

Figure 4. Morpho-biometric characteristics of the radish in the Bi contaminated soil

In Haplic Arenosols Eutric with Bi 10 and $100 \mathrm{CPC}$, inhibition of activity of dehydrogenases was also observed by 33 and $58 \%$ of the control were contaminated. There is a dose-effect relationship. The maximum toxic effect in the soil of Bi 10 and $100 \mathrm{CPC}$ was determined for the total number of bacteria - 43\% and 46\%, respectively. A 29\% decrease in catalase activity from control was recorded when 100 CPC Bi was added to Haplic Arenosols Eutric. By adding 10 and 100 CPC Bi to Haplic Arenosols Eutric, radish roots are inhibited by $25 \%$ and $40 \%$ of control. IIBS Haplic Arenosols Eutric with Bi 10 and 100 CPC decreased by $21 \%$ and $39 \%$, respectively.

A low dose (1 CPC) of Bi nitrate resulted in unreliable stimulation of radish seed germination when applied to all types of soils. Nagata (2015), studying the effect of Bi nitrate on the root length of Arabidopsis thaliana, found that high concentrations inhibit root growth, while low concentrations, on the contrary, stimulate. The total number of bacteria was significantly reduced when applied to all types of soils, regardless of the dose of $\mathrm{Bi}$. The largest decrease in the total number of bacteria was recorded at a dose of $100 \mathrm{CPC}$ for Haplic Cambisols Eutric at $65 \%$ of the control. In the overwhelming majority of cases, a decrease in the total number of bacteria, catalase and dehydrogenase activity, as well as the length of radish roots was observed (Figure 4). When comparing soil resistance to Bi pollution, the following series was obtained: Haplic Chernozem Calcic (84) > Haplic Arenosols Eutric (78) > Haplic Cambisols Eutric (72).

The light particle size distribution of Haplic Arenosols Eutric and the acidic reaction of the Haplic Cambisols Eutric medium ( $\mathrm{pH}=5.8)$, as well as the low organic matter content (1.8 and 2.3\%, respectively), contribute to the high mobility and, therefore, the high ecotoxicity of Bi in these soils.

\section{Calculate and assessment of bismuth contaminated soils by the environmental regional maximum permissible concentration (rMPCs)}

Previously, it was found that soil contamination with chemicals causes a violation of its ecosystem functions in a strict sequence: information functions, biochemical, physicochemical, chemical and integral functions and physical (Kolesnikov et al., 2019). When developing environmental standards for soil contamination, we used this sequence. IIBS soil is an objective indicator of dysfunction of a particular ecosystem. Prevention of degradation of soil ecosystem functions is an important task in the development of environmental standards. Thus, a drop in IIBS of more than $10 \%$ indicates a serious deterioration in soil functioning. It is proposed to call this value for each type of soil the regional maximum permissible concentration (rMPCs) for a specific pollutant in the soil (Kolesnikov et al., 2019). To determine the rMPCs of pollutants, we used a regression equation describing the dependence of the IIBC fall on the proportion of pollutants in the soil.

According to Table 3, the concentration of $8.5 \mathrm{mg} \mathrm{kg}^{-1} \mathrm{Bi}$ in Haplic Chernozem Calcic corresponds to a $10 \%$ decrease in soil IIBS. Biconcentration of $8.5 \mathrm{mg} \mathrm{kg-1}^{-1}$ should be considered the MPC for Bi in Chernozem. Thus, the rMPC of Bi for Haplic Chernozem Calcic is $8.5 \mathrm{mg} \cdot \mathrm{kg}^{-1}$, Haplic Arenosols Eutric- $2.2 \mathrm{mg} \mathrm{kg}^{-1}$, and Haplic Cambisols Eutric- $1.8 \mathrm{mg} \mathrm{kg}^{-1}$. 
Table 3. Scheme of environmental standards for bismuth contaminated soils in the South of Russia related to a degree of failure of ecosystem functions

\begin{tabular}{|c|c|c|c|c|}
\hline Soil & Not polluted & $\begin{array}{c}\text { Little degree of } \\
\text { pollution }\end{array}$ & $\begin{array}{c}\text { Average degree of } \\
\text { pollution }\end{array}$ & $\begin{array}{c}\text { Strong degree of } \\
\text { pollution }\end{array}$ \\
\hline Degree of soil IIBS decline ${ }^{*}$ & $<5 \%$ & $5-10 \%$ & $10-25 \%$ & $>25 \%$ \\
\hline $\begin{array}{l}\text { Disturbed ecosystem } \\
\text { functions }\end{array}$ & - & Informational value & $\begin{array}{c}\text { Chemical, physical and } \\
\text { chemical, biochemical, holistic }\end{array}$ & Physical \\
\hline Soil & \multicolumn{4}{|c|}{ Bismuth concentration in soil, $\mathrm{mg} \mathrm{kg}^{-1}$} \\
\hline Haplic Chernozem Calcic & $<2.5$ & $2.5-8.5$ & $8.5-350$ & $>350$ \\
\hline Haplic Arenosols Eutric & $<0.9$ & $0.9-2.2$ & $2.2-30$ & $>30$ \\
\hline Haplic Cambisols Eutric & $<0.8$ & $0.8-1.8$ & $1.8-20$ & $>20$ \\
\hline Soil remediation techniques & Non-required & $\begin{array}{l}\text { Phyto remediation, } \\
\text { washings }\end{array}$ & $\begin{array}{l}\text { Chemical } \\
\text { reclamation }\end{array}$ & $\begin{array}{c}\text { Full removal of } \\
\text { contaminated layer }\end{array}$ \\
\hline
\end{tabular}

*IIBS evaluation according to Kolesnikov et al. (2019).

${ }^{* *}$ Classification of soil ecosystem functions according to Dobrovolskiy and Nikitin (2006).

In addition, Table 3 presents the most effective soil remediation methods when the soil is contaminated with a specific concentration of $\mathrm{Bi}$. The higher the Bi concentration in the soil, the more necessary chemical remediation and removal of the topsoil. The proposed rMPCs should be used in the implementation of various environmental protection measures, such as: environmental impact assessment (EIA), selection of methods for remediation of contaminated soils, etc. rMPCs should be used to assess soils not only in the South of Russia, but also similar soils around the world.

\section{Conclusion}

The results obtained showed that the soils contaminated with bismuth in the studied soils generally lose their biological properties: the total number of bacteria and the enzymatic activity (catalase and dehydrogenases) are reduced. The indicators of phytotoxicity (germination of radish seeds) increase when bismuth 3 and $30 \mathrm{mg} \mathrm{kg}^{-1}$ is added to the soil. The degree of deterioration of biological properties depends on two factors: the concentration of bismuth in the soil and the period of time after the start of contamination. The calculation and assessment of soil bismuth contamination by ecological regional maximum permissible concentrations (MPC) showed that, bismuth rMPCs for Haplic Chernozem Calcic is 8.5 mg kg-1, Haplic Arenosols Eutric - $2.2 \mathrm{mg} \mathrm{kg}^{-1}$ and Haplic Cambisols Eutrics - $1.8 \mathrm{mg} \mathrm{kg}^{-1}$. The established rMPCs should be referred to when implementing various environmental activities such as: environmental impact assessment (EIA), soil and ecosystem monitoring practices, choice of polluted soil reclamation techniques, risk assessment of technogenic disasters, soil certification, etc. The suggested rMPCs can be referred to for soil assessment not only in the South of Russia but also in similar soils worldwide.

\section{Acknowledgements}

Authors would also like to express acknowledgements to the criticism and constructive comments of the anonymous referees. The study was carried out with the support of the Ministry of Science and Higher Education of the Russian Federation within the framework of a state assignment (Southern Federal University, project No. 0852-2020-0029) and state support of the leading scientific schools of the Russian Federation (grant of the President of the Russian Federation SSh-2511.2020.11).

\section{References}

Akay, A., Sert, D., 2020. The effects of whey application on the soil biological properties and plant growth. Eurasian Journal of Soil Science 9 (4): 349-355.

Akimenko, Y.V., Kolesnikov, S.I., Kazeev, K.S., Minnikova, T.V., 2018. Biodiagnostics of consequences of soil contamination with modern biocides. 18 ${ }^{\text {th }}$ International Multidisciplinary Scientific GeoConference SGEM 2018. Conference Proceedings. 2-5 July 2018. Albena, Bulgaria. 18: 41-48.

Alekseenko, V.A., Alekseenko, A.V., 2013. Chemical elements in geochemical systems. Soil clarks of residential landscapes. Southern Federal University Press, Rostov on Don, Russia. 380p. [in Russian].

Cortada, U., Hidalgo, M.C., Martínez, J., Rey, J., 2018. Impact in soil caused by metal (loid)s in lead metallurgy. The case of Cruz Smelter (Southern Spain). Journal of Geochemical Exploration 190: 302-313.

Dobrovolskiy, G., Nikitin, E., 2006. Soil ecology - doctrine about ecological functions of soils. Moscow State University Nauka, Moscow, Russia. 362p. [in Russian].

Egorysheva, A.V., Ellert O.G., Zubavichus Y.V., Gajtko O.M., Efimov N.N., Svetogorov R.D., Murzin V.Yu., 2015. New complex bismuth oxides in the $\mathrm{Bi}_{2} \mathrm{O}_{3}-\mathrm{NiO}-\mathrm{Sb}_{2} \mathrm{O}_{5}$ system and their properties. Journal of Solid State Chemistry 225: 97-104. 
Elekes, C.C., Busuioc, G., 2010. The mycoremediation of metals polluted soils using wild growing species of mushrooms. Latest Trends on Engineering Education 1(1): 36-39. 22-24 July 2010, Varna, Bulgaria.

GOST RISO 22030-2009, 2009. National standard of Russian Federation. Soil quality. Biological methods. Chronic phytotoxicity for higher plants, Moscow, Russia. 20p.

Kabata-Pendias, A., Pendias, X., 2010. Trace Elements in Soils and Plants. 4th Edit. Boca Raton, CRC Press, FL, USA. 548p.

Kasimov, N., Vlasov, D., 2012.Technophilic ability of chemical elements in the early XXI century. Moscow State University. Moscow, Russia. Geography 5(1): 15-22 [in Russian].

Kızılkaya, R., Yertayeva, Z., Kaldybayev, S., Murzabayev, B., Zhapparova, A., Nurseitov, Z., 2021. Vermicomposting of anaerobically digested sewage sludge with hazelnut husk and cow manure by earthworm Eisenia foetida. Eurasian Journal of Soil Science 10 (1): 38-50.

Kolesnikov, S.I., Kazeev, K.S., Akimenko, Y.V., 2019. Development of regional standards for pollutants in the soil using biological parameters. Environmental Monitoring and Assessment 191: 544.

Kolesnikov, S.I., Tsepina, N.I., Sudina, L.V., Minnikova, T.V., Kazeev, K. S., Akimenko, Y.V., 2020. Silver ecotoxicity estimation by the soil state biological indicators. Applied and Environmental Soil Science Article ID 1207210.

Li, Z.Y, Ma, Z.W., van der Kuijp T.J., Yuan, Z.W., Huang, L., 2014. A review of soil heavy metal pollution from mines in China: Pollution and health risk assessment. Science of the Total Environment 468: 843-853.

Liu, B., Wu, F., Li, X., Fu, Zh., Deng, Q., Mo, C., Zhu, J., Zhu. Y., Liao, H., 2011. Arsenic, antimony and bismuth in hu-man hair from potentially exposed individuals in the vicinity of antimony mines in Southwest China. Microchemical Journal 97(1): 20-24.

Meyer, J., Schmidt, A., Michalke, K., Hensel, R., 2007. Volatilisation of metals and metalloids by the microbial population of analluvial soils. Systematic and Applied Microbiology 30(3): 229-238.

Murata, T., 2006. Effects of bismuth contamination on the growth and activity of soil microorganisms using thiols as model compounds. Journal of Environmental Science and Health - Part A Toxic/Hazardous Substances and Environmental Engineering 41(2): 161-172.

Murtić, S., Sijahović, E., Čivić, H., Tvica, M., Jurković, J., 2020. In situ immobilisation of heavy metals in soils using natural clay minerals. Plant, Soil and Environment 66: 632-638.

Nagata, T., 2015. Growth inhibition and IRT1 induction of Arabidopsis thaliana in response to bismuth. Journal of Plant Biology 58(5): 311-317.

Omouri, Z., Hawari, J., Fournier, M, Robidoux, P.Y., 2018. Bioavailability and chronic toxicity of bismuth citrate to earthworm Eisenia andrei exposed to natural sandy soil. Ecotoxicology and Environmental Safety 147: 1-8.

Reus, T.L., Machado, T.N., Bezerra, A.G.Jr., Marcon, B.H., Paschoal, A.C.C., Kuligovski, C., de Aguiar, A.M., Dallagiovanna, B., 2018. Dose-dependent cytotoxicity of bismuth nanoparticles produced by LASiS in a reference mammalian cell line BALB/C 3T3. Toxicology in Vitro 53: 99-106.

Soriano, A., Pallarés, S., Pardo, F., Vicente, A.B., Sanfeliu, T., Bech, J., 2012. Deposition of heavy metals from particulate settleable matter in soils of an industrialised area. Journal of Geochemical Exploration 113: 36-44.

Wei, C., Deng, Q., Wu, F., Fu, Z., Xu, L., 2011. Arsenic, antimony, and bismuth uptake and accumulation by plants in an old antimony mine, China. Biological Trace Element Research 144(1-3): 1150-1158.

WRB, 2015. International soil classification system for naming soils and creating legends for soil maps. World Soil Resources Reports No. 106. Food and Agriculture Organization of the United Nations (FA0), Rome, Italy. 192p. Available at [access date: 11.11.2020]: http://www.fao.org/3/i3794en/I3794en.pdf

Xiong, Q.L., Zhao, W.J., Guo, X.Y., Shu, T.T., Chen, F.T., Zheng, X.X., Gong, Z.N., 2015. Dustfall heavy metal pollution dur-ing winter in North China. Bulletin of Environmental Contamination and Toxicology 95(4): 548-554.

Yurgenson, G.A, Gorban, D.N., 2017. Features of bismuth distribution in soils, technosoils and plants of the Sherlovoaya mountain ore region. International Journal of Applied and Fundamental Research 7: 111-116 [in Russian].

Zhang, C., Qiao, Q., Piper, J.D.A., Huang, B., 2011a. Assessment of heavy metal pollution from a Fe-smelting plant in urban river sediments using environmental magnetic and geochemical methods. Environmental Pollution 159(10): 3057-3070.

Zhang, N., Fu, N., Fang, Z., Feng, Y., Ke, L., 2011b. Simultaneous multi-channel hydride generation atomic fluorescence spectrometry determination of arsenic, bismuth, tellurium and selenium in tea leaves. Food Chemistry 124(3): 1185-1188. 